\title{
Calcium and Oxalic Acid Contents of Sugar Beet Plant in Salinity Stress
}

\author{
Bülent TOPCUOĞLU
}

\begin{abstract}
Sugar beet plants were grown in peat-perlite substrate by using a non-recirculating nutrient film growing system. The effect of $\mathrm{NaCl}$ addition at 0 (control), 25, 50 and $75 \mathrm{mM}$ concentrations to nutrient solution on calcium and oxalic acid contents in the leaf and root tissues of sugar beet plant were examined. $\mathrm{NaCl}$ applications decreased leaf and root dry matters and calcium contents in the leaf and root tissues of sugar beet. Oxalic acid content was increased in the leaf tissue while decreasing in the root tissue by $\mathrm{NaCl}$ applications. Physiologically active oxalic acid amount was only determined in the root tissue at the highest $\mathrm{NaCl}$ level. Although $\mathrm{Ca}$ deficiency induced by low plant $\mathrm{Ca}$ uptake due to high salinity, physiologically active oxalic acid accumulation in the root tissue of sugar beet may be a limiting factor on $\mathrm{Ca}$ availability and plant productivity in salinity stress.
\end{abstract}

Keywords - Salinity, calcium, oxalic acid, sugar beet.

\section{INTRODUCTION}

Oxalic acid is a common constituent of plants and is found in almost all plant families, occurring as free acid, soluble salts of potassium, sodium and magnesium and as insoluble salts of calcium and iron. High oxalic acid concentrations in leaves of plant species, especially those used as green leafy vegetables in the daily diets, have been of concern because of the harmful health effects associated with the intake of high oxalic acid [1].

Oxalate-rich foods are usually minor components in human diets but are sometimes important in seasonal diets in certain areas of the world. Plants such as spinach and beetroot are well known for containing higher concentrations of oxalates than other plants [2].

Oxalic acid is not only effects diet mineral availability but also effects plant $\mathrm{Ca}$ metabolism. Calcium present in plant foods exists primarily as a complex in which it is bound to substances such as oxalate, phytate, fiber, fatty acid, protein, and/or other anions. Most studies suggest that oxalate is an antinutrient that renders calcium and sometimes other minerals unavailable for nutritional absorption by human. Most of the findings showed that the general conclusion that the more calcium in the form of the oxalate salt, the less calcium available for nutritional absorption [3].

$\mathrm{Ca}$ is a very immobile essential macro element once deposited in a tissue. Ca immobility may result from ion complexes as oxalate or other insoluble forms and from binding to the cell wall making it unavailable for transport [4].

Prof. Dr. Bülent Topcuoğlu is with the Akdeniz University Vocational School of Technical Sciences, Antalya, Turkey (e-mail: btoglu@akdeniz.edu.tr)
Ca deficiency causes of black tip at the apex of the petiole of sugar beet. The prevalence and severity of black-tip formation has been consistently associated with factors causing formation of insoluble Ca compounds such as phosphate or oxalate at the growing tip [5]. Excessive concentrations of soluble salts in the substrate have also been associated with black-tip formation and can cause a decreased Ca uptake even when the measurable $\mathrm{Ca}$ ratio $(\mathrm{Ca} /$ soil solution salts) appears to be adequate [6]. $\mathrm{Ca}$ is concentrated in the form of calcium oxalate and may be precipitated in plant cells and thus oxalic acid limits $\mathrm{Ca}$ availability for continued shoot growth [7].

Another factor affecting plant $\mathrm{Ca}$ uptake is soil salinity. Salinity is a major factor in reducing plant growth and productivity. In saline conditions plant $\mathrm{Ca}$ uptake significantly be reduced and the rate of $\mathrm{Ca}$ uptake decreased linearly with increasing salinity [8]. Understanding the physiology of high oxalic acid occurring plants under salinity conditions is important for an effective approach to the salinity and calcium nutrition problem.

\section{MATERIALS AND MethodS}

The experiment was carried out in greenhouse under controlled and standardized condition. Sugar beet seeds (Beta vulgaris L. Cv. Evita) were sown in perlite and after germination seedlings were irrigated and allowed to grow approximately $5 \mathrm{~cm}$ of shoot length. These seedlings were transferred to $10 \mathrm{~L}$ pots containing washed peat + perlite mixture (1:1) substrate as one plant per pot and received basal nutrient solution plus the treatments of $\mathrm{NaCl}$. Each pot had a hole at the bottom to facilitate drainage when renewing the nutrient solution.

The composition of basal nutrient solution was: $1.25 \mathrm{mM}$ $\mathrm{KH}_{2} \mathrm{PO}_{4}, 2.00 \mathrm{mM} \mathrm{MgSO}$, $4.20 \mathrm{mM} \mathrm{Ca}\left(\mathrm{NO}_{3}\right)_{2}, 3.60 \mathrm{mM}$ $\mathrm{KNO}_{3}, 1.50 \mathrm{mM} \mathrm{NH}_{4} \mathrm{NO}_{3}, 1.87 \mathrm{mM} \mathrm{K} \mathrm{SO}_{4}$. Iron (FeEDDHA), Boron $\left(\mathrm{Na}_{2} \mathrm{~B}_{4} \mathrm{O}_{7} \cdot \mathrm{H}_{2} \mathrm{O}\right)$, Manganese $\left(\mathrm{MnSO}_{4} \cdot \mathrm{H}_{2} \mathrm{O}\right)$, Zinc $\left(\mathrm{ZnSO}_{4} .7 \mathrm{H}_{2} \mathrm{O}\right)$, Copper $\left(\mathrm{CuSO}_{4} .5 \mathrm{H}_{2} \mathrm{O}\right)$, Molybdenum $\left(\mathrm{Na}_{2} \mathrm{MoO}_{4} \cdot 2 \mathrm{H}_{2} \mathrm{O}\right)$ were also included at the rates of $40,30,10$, $4,0.75,0.5 \mu \mathrm{mol} \mathrm{l}^{-1}$, respectively. $\mathrm{NaCl}$ was applied to basal nutrient solution at 0 (control), 25, 50 and $75 \mathrm{mM}$. Each $\mathrm{NaCl}$ treatment was replicated four times in a randomised plot design.

Pots were irrigated every day with nutrient solutions contained above mentioned $\mathrm{NaCl}$ levels. Pots were leached with distilled water every three irrigation to prevent salt accumulation and then nutrient solution was added as previously mentioned. All plants were harvested and weighed during 2 months of growth. All sugar beet plants were 
removed from the pot and divided two parts as the upper half (leaves) and lower half tissues (roots) and then samples were washed with distilled water.

Plant material was dried at $65^{\circ} \mathrm{C}$, weighed, blended and wet ashed with $\mathrm{HNO}_{3}+\mathrm{HClO}_{4}$. In wet ashed samples total $\mathrm{Ca}$ was determined by atomic absoption spectrofotometry. In dried plant samples total oxalic acid was determined by $\mathrm{KMnO}_{4}$ titration medhod [9]. Physiologically active oxalic acid was calculated as the excess of equivalent amount of total oxalic acid than that of calcium [10].

Statistical analysis were performed by using SPSS-16 for windows program.

\section{RESULTS AND DISCUSSION}

$\mathrm{NaCl}$ applied to nutrient solutions decreased plant dry matter and fruit yield. At the application of $75 \mathrm{mM} \mathrm{NaCl}$, plant dry matter was sharply dimished (Figure 1). The findings on plant yield decrease by $\mathrm{NaCl}$ applications are in concordance with previous results [11].

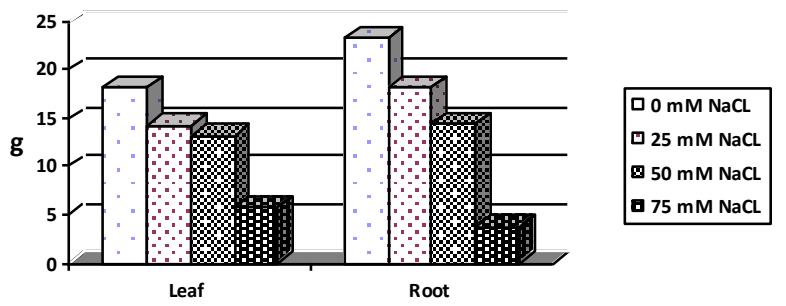

Fig 1. Leaf and tuber dry matter amounts (g/pot) of sugar beet grown in different $\mathrm{NaCL}$ levels.

Oxalic acid contents were decreased both in the leaf and root tissues by the applications of $\mathrm{NaCl}$. In control treatment, oxalic acid content was the highest rate in the sugar beet tissues (Figure 3).

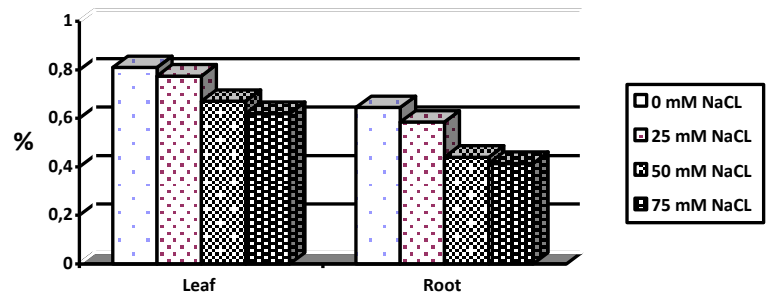

Fig 2. Leaf and tuber oxalic acid contents (\%) of sugar beet grown in different NaCL levels.

$\mathrm{Ca}$ contents in the leaf and roots of sugar beet were decreased by the applications of $\mathrm{NaCl}$ (Figure 3). Typical Ca deficiency symptoms in sugar beet leaves were recorded by the applications of $\mathrm{NaCl}$ to nutrient solution. No deficiency symptoms were observed in control application. The data that decreasing $\mathrm{Ca}$ content was related with the salt applications confirm the previous findings [12]. Leaf tissue contained higher content of $\mathrm{Ca}$ than the root tissue.

It is thought that the incidence of $\mathrm{Ca}$ deficiency is not only increased depending on the low $\mathrm{Ca}$ content of the sugar beet in salinity stress, but also oxalic acid complexes with $\mathrm{Ca}$ and reduces its metabolic availability and translocation to upper tissues. It is reported that higher concentrations of oxalic acid in the upper portions of susceptible Burley tobacco varieties be observed and it fixed $\mathrm{Ca}$ and reduced its translocation to and metabolic accessibility in apical tissues [13].

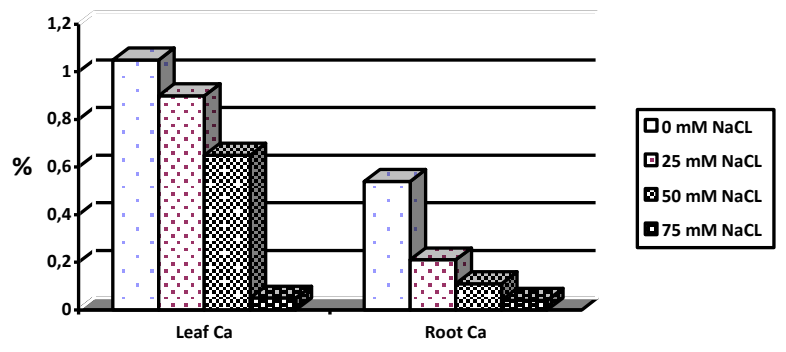

Fig 3. Leaf and tuber calcium contents (\%) of sugar beet grown in different NaCL levels.

Physiologically active oxalic acid (PAOA) was a stoichiometric value and calculated as the excess of equivalent amount of total oxalic acid than that of calcium [10] and represents potential health hazards oxalate rich foods. PAOA was recorded in the highest $\mathrm{NaCl}$ application $(75 \mathrm{mM})$ in the leaf tissue, and physiologically active oxalic acid amount was increased by $\mathrm{NaCl}$ applications (Figure 4). Physiologically active oxalic acid in the leaves tissues at $75 \mathrm{~mm} \mathrm{NaCl}$ level and in the root at $\mathrm{NaCl}$ tretaments were occured as a result of lower $\mathrm{Ca}$ content at this level. Although oxalic acid content was also decreased by $\mathrm{NaCl}$ treatments, this subsidence rate was lower than for $\mathrm{Ca}$.

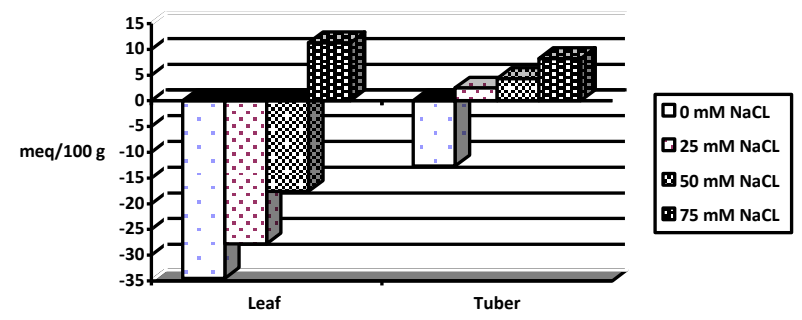

Fig 4. Leaf and root PAOA amounts of sugar beet grown in different NaCL levels.

Physiologically active oxalic acid is equal to soluble oxalate which is a stoicheiometric value and means a free form of oxalic acid which is not fixed hardly in insoluble form by divalent cations. In this meaning physiologically active oxalic acid is thought to be an important factor limiting $\mathrm{Ca}$ availability and mobility in plant tissues. High concentrations of oxalic acid in stems have resulted in precipitation of $\mathrm{Ca}$ before it reached such organs as leaves and fruits [14].

\section{CONCLUSION}

In saline conditions plant $\mathrm{Ca}$ uptake is mostly depressed by $\mathrm{Na}$ or other metallic cations. On the other hand, due to highly significant relations between insoluble $\mathrm{Ca}$ and oxalic acid in the oxalate rich plants, $\mathrm{Ca}$ is mostly precipitated in the plant 
tissues and limiting its availability for continued shoot growth. In addition to $\mathrm{Ca}$ starvation induced by low $\mathrm{Ca}$ uptake due to high salinity, higher oxalic acid synthesis in the sugar beet may also be thought as a limiting factor on Ca availability and plant productivity.

The strategies including the improvement of lower oxalate accumulating plant varieties, and well-organized fertilization programs for low oxalate plant cultivation should be planned for effective plant nutrition in saline conditions and low oxalate food consumption for the people.

\section{REFERENCES}

[1] R.P. Usha, B.B. Bernanrd and J.M. Richard. 2004. "Oxalic acid concentrations in Purslane (Portulaca oleraceae L.) is altered by the stage of harvest and the nitrate to ammonium ratios in hydroponics". Scientia Horticulturae, 2004, 102, 267-275

[2] G.P. Savage, L. Vanhanen, S.M. Mason and A.B. Ross. "Effect of Cooking on the Soluble and Insoluble Oxalate Content of Some New Zealand Foods". Journal of Food Composition and Analysis, 2000, 13, 201-206.

[3] P.A. Nakata and M.M. McConn. "Calcium oxalate content affects the nutritional availability of calcium from Medicago truncatula leaves. Plant Science”, 2007, 172, 958-96.

[4] I.B. Ferguson. "The movement of calcium in non-vascular tissue of plants". Commun. in Soil Sci. Plant Anal., 1979, 10(1-2):217-224.

[5] A. Ulrich and M.A.E. Mostafa. "Calcium nutrition of the sugarbeet". Communication in soil science and plant analysis, 1976, 7(5): 483-495.

[6] W.H. Greenleaf and F. Adams. "Genetic control of blossom-end rot disease in tomatoes". J: Am. Soc. Hort. Sci., 1969, 94:248-250.

[7] J.P. Behling, W.H. Gabelman and G.C. Gerloff. "The distribution and utilization of calcium by two tomato (Lycopersicon esculentum Mill.) lines differing in calcium efficiency when grown under low-Ca stress". Plant and Soil, 1989, 113:189-196.

[8] P. Adams and L.C. Ho. "Effects of environmental on the uptake and distribution of calcium in tomato and on the incidence of blossom-end rot. Plant and Soil", 1993, 154(1):127-132.

[9] A. Adriaanse and I.E. Robbers. "Über eine modifizierte gessamtoxalat bestimmung in gemüsen“. Z. Lebensm.-Unters. U. Fors., 1970, 141:158-160.

[10] R.M. Allison. "Soluble oxalates, ascorbic and other constituents of rhubarb varieties". J. Sci. Fd. Agric., 1966, 17:554-557.

[11] M.V. Lopez and S.M.E. Satti. "Calcium and potassium-enhanced growth and yield of tomato under sodium chloride stress". Plant Science Limeric, 1966, 114(1):19-27.

[12] S.M.A. Faiz, S.M. Ullah, A.K.M.A Hussain, A.T.M.M. Kamal, and A. Sattar, A. "Yield, mineral contents and quality of tomato (Lycopercicon esculentum) under salt stress in a saline soil". Current Agriculture, 1994, 18(1-2):9-12.

[13] D.M. Brumagen and A.J. Hiatt. "The relationship of oxalic acid to the translocation and utilization of calcium in Nicotiana tabacum". Plant and Soil, 1966, 24:239-249.

[14] H.J. Evans and R.V. Troxler. "Relation of calcium nutrition to the incidence of blossom-end rot in tomatoes". Am. Soc. Hort. Sci. Proc., 1953, 61:346-352.

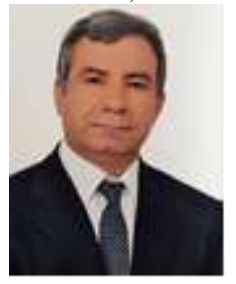

[Bülent TOPCUOĞLU has born in Turkey, 1966; obtained PhD degree in 1993 from the Ankara University, Turkey in Soil Science and Plant Nutrition department. He is currently working as a Professor on Soil Science and Plant Nutrition, Soil Pollution and Environmental Sciences topics, at the Akdeniz University Vocational school of Tecnical Sciences, Antalya TURKEY. Author has done more than one hundred research publications to his credit.

Prof. Topcuoğlu has a scientific member of many organizations and chaire of many conferences organized by IAAST, IAE, CBMSR, IICBEE, IIENG and PSRC in İstanbul and Antalya, TURKEY. 